DE

M E D I C I N A

T R O P I C A L

$\mathrm{DE}$

S ÃO PAULO

JOURNAL OF THE SÃO PAULO INSTITUTE OF TROPICAL MEDICINE

(1) Fundação Oswaldo Cruz, Centro de Pesquisas Aggeu Magalhães, Departamento de Virologia e Terapia Experimental, Recife, Pernambuco, Brazil

(2) Universidade Federal de Pernambuco, Laboratório de Imunopatologia Keizo Asami, Setor de Virologia, Recife, Pernambuco, Brazil.

Correspondence to: José Valter Joaquim Silva Júnior

Fundação Oswaldo Cruz, Centro de Pesquisas Aggeu Magalhães, Departamento de Virologia e Terapia Experimental, CEP 50670-420, Recife, PE, Brazil

Tel: $+55812101-2564$

E-mail: josevalterjsilvajr@gmail.com

Received: 26 January 2017

Accepted: 24 March 2017

\section{Perspectives on the Zika outbreak: herd immunity, antibody- dependent enhancement and vaccine}

Recife, January 26, 2017

Dear editor

Zika virus (ZIKV) is a member of the family Flaviviridae, which comprises mosquito-borne viruses that pose major public health threats, such as Dengue (DENV) and Yellow Fever (YFV). ZIKV infections in humans were first reported in 1952 (Nigeria), and since then have spread around the world. The virus has probably arrived in Brazil in early 2015, and has been associated with neurological symptoms, including microcephaly ${ }^{1}$.

Here, we used the data concerning the DENV cases during the last years in Brazil $^{2}$ to infer about future ZIKV outbreaks. The possibility of infection by any DENV serotype creates an epidemiological profile where each outbreak corresponds to the circulation of a serotype in a non-exposed population. Unlike the DENV, ZIKV has only one serotype, although two ZIKV lineages (Asian and African) have been reported. Indeed, it has been shown that sera from mice infected with either African or Asian ZIKV lineages were capable of neutralizing equivalently homologous and heterologous ZIKV lineages ${ }^{3}$. Thus, one only ZIKV serotype may induce a different epidemiological scenario of DENV, with a longer time interval between outbreaks and explain its probable forthcoming epidemiology. In Brazil, for example, the arrival of ZIKV created a peak in the number of cases in a naïve population ${ }^{4}$. However, after the virus established itself in the population, we expected an increase in the number of people who develop immunity, causing a decrease in the number of cases (Figure 1A). Similar situation is likely to occur with Chikungunya virus (CHIKV) infection, an emergent single serotype alphavirus without vaccine available, which usually shows epidemiological silencing of 3-4 years ${ }^{5}$.

The decrease in the number of zika disease cases after the $8^{\text {th }}$ Epidemiological Week (EW) of 2016 (February $21^{\text {st }}$ to $27^{\text {th }}$ ), cannot yet be explained by herd immunity, but is probably due to vector seasonal features, as reported for dengue cases during the same time ${ }^{4,6}$. Therefore, despite the 130,759 confirmed cases of zika disease until the EW $4(2017)^{7}$, it may still take some years before the herd immunity decreases the number of cases, which will remain lower until the emergence of a new naïve human generation, leading to a second outbreak (Figure 1A).

Under these circumstances, it is necessary to discuss proper measures to avoid a rise in ZIKV cases. In Brazil, environmental education and vector control were not able to contain DENV infections in the past decades, and did not prevent the emergence of other arboviruses transmitted by the same mosquito vector (e.g. ZIKV and CHIKV) ${ }^{8}$.

Therefore, vaccination appears to be the best way to prevent new future ZIKV outbreaks (Figure 1B). Nevertheless, it is important to acknowledge that cross-reaction between DENV and ZIKV antibodies has been reported and subneutralizing concentrations of antibodies to DENV or ZIKV could enhance the viral entry into cells and contribute to the pathogenesis; a phenomenon called antibodydependent enhancement (ADE) ${ }^{9,10}$.

This should be considered when analyzing the process of vaccination against dengue (already available) ${ }^{11}$ and zika (still under research and development process $)^{12}$. A prudent way of thinking about vaccination and strategies for vaccine development for ZIKV and DENV, ensuring their simultaneous control would 

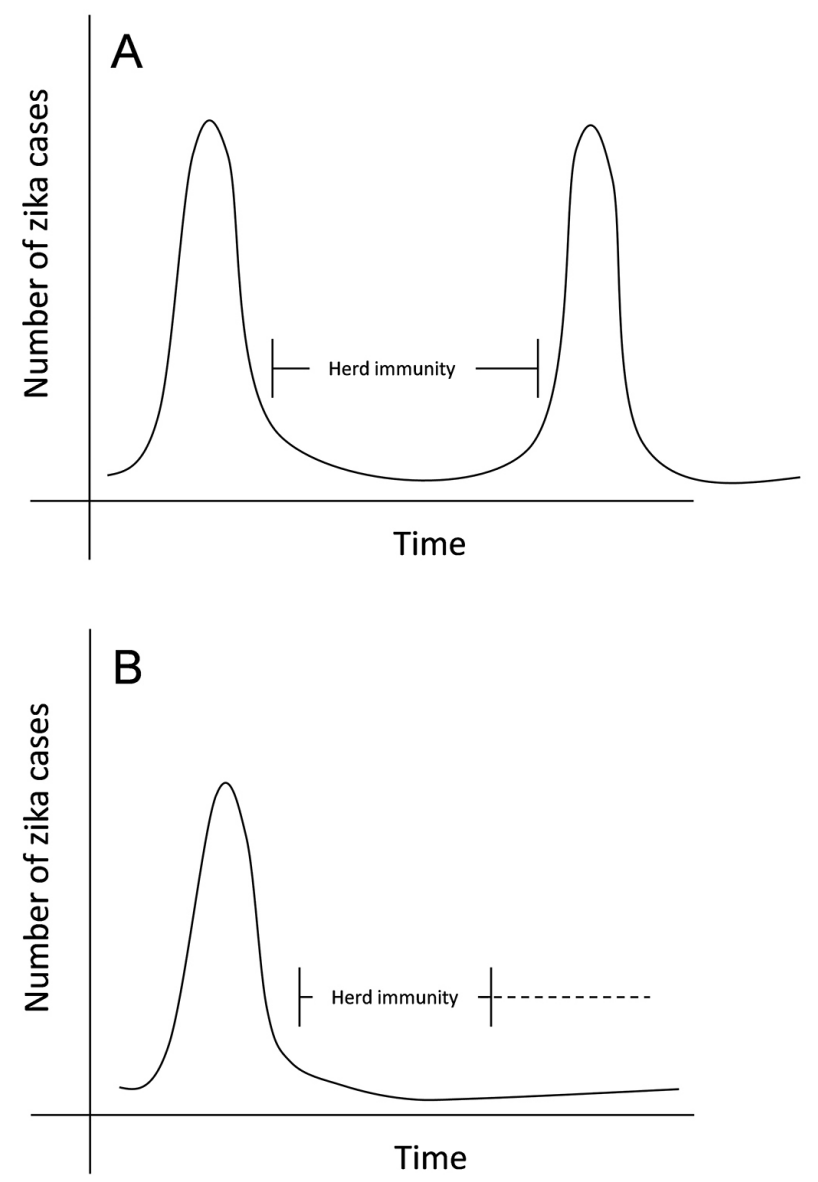

Figure 1 - Possible dynamics of zika disease before $(A)$ and after $(B)$ vaccination. For illustrate the probable epidemiological profile of the virus before and after vaccination, the figure was constructed from the concept of herd immunity and the existence of only one ZIKV serotype. The numbers of confirmed cases of zika disease were not used because the outbreak is still at the beginning and does not reflect the timeline described in the figure.

be: i) synchronization of DENV and ZIKV vaccination calendars with a simultaneous immunization program; ii) production of a pentavalent vaccine (DENV 1-4 plus ZIKV); and iii) identification of DENV- and ZIKV- specific neutralizing epitopes to develop a safer vaccine and avoid the ADE risk.

Finally, knowing that herd immunity and ADE events play an important role concerning ZIKV infections, we believe that the future success in ZIKV control relies on the strengthening of the relationship between public health and molecular virology.

José Valter Joaquim Silva Júnior ${ }^{1}$ Thaísa Regina Rocha Lopes ${ }^{2}$ Edmilson Ferreira de Oliveira-Filho ${ }^{1}$ Renato Antonio dos Santos Oliveira ${ }^{1}$ Laura Helena Vega Gonzales Gil ${ }^{1}$

\section{REFERENCES}

1. Abushouk AI, Negida A, Ahmed H. An updated review of Zika virus. J Clin Virol. 2016;84:53-8.

2. Teixeira MG, Siqueira JB Jr, Ferreira GL, Bricks L, Joint G. Epidemiological trends of dengue disease in Brazil (20002010): a systematic literature search and analysis. PLoS Negl Trop Dis. 2013; 7:e2520.

3. Dowd KA, DeMaso CR, Pelc RS, Speer SD, Smith AR, Goo L, et al. Broadly neutralizing activity of Zika virus-immune sera identifies a single viral serotype. Cell Rep. 2016;16:1485-91.

4. Brasil. Ministério da Saúde. Secretaria de Vigilância em Saúde. Zika vírus: perfil epidemiológico em mulheres. Bol Epidemiol. 2016;47(37):1-7. [cited 2017 Jan 20]. Available from: http:// combateaedes.saude.gov.br/images/pdf/Virus_Zika_perfil_ epidemiologico_em_mulheres.pdf

5. Josseran L, Paquet C, Zehgnoun A, Caillere N, Le Tertre A, Solet JL, et al. Chikungunya disease outbreak, Reunion Island. Emerg Infect Dis. 2006;12:1994-5.

6. Brasil. Ministério da Saúde. Secretaria de Vigilância em Saúde. Monitoramento dos casos de dengue, febre de chikungunya e febre pelo vírus Zika até a Semana Epidemiológica 49, 2016. Bol Epidemiol. 2016;47(38):1-10. [cited 2017 Jan 20]. Available from: http://portalsaude.saude.gov.br/images/ pdf/2016/dezembro/20/2016-033---Dengue-SE49-publicacao. pdf

7. Brasil. Ministério da Saúde. Secretaria de Vigilância em Saúde. Monitoramento dos casos de dengue, febre de chikungunya e febre pelo vírus Zika até a Semana Epidemiológica 4, 2017. Bol Epidemiol. 2017;48(5):1-9. [cited 2017 Jan 20]. Available from: http://portalarquivos.saude.gov.br/ images/pdf/2017/fevereiro/17/Monitoramento-dos-casos-dedengue--febre-de-chikungunya-e-febre-pelo-v--rus-SemanaEpidemiologica-4-2017.pdf

8. da Silva Augusto LG, Gurgel AM, Costa AM, Diderichsen F, Lacaz FA, Parra-Henao G, et al. Aedes aegypti control in Brazil. Lancet. 2016;387:1052-3.

9. Dejnirattisai W, Supasa P, Wongwiwat W, Rouvinski A, BarbaSpaeth G, Duangchinda T, et al. Dengue virus sero-crossreactivity drives antibody-dependent enhancement of infection with zika virus. Nat Immunol. 2016;17:1102-8.

10. Stettler K, Beltramello M, Espinosa DA, Graham V, Cassotta A, Bianchi S, et al. Specificity, cross-reactivity, and function of antibodies elicited by Zika virus infection. Science. 2016;353:823-6.

11. World Health Organization. Dengue vaccine research. Geneva: WHO; 2016 [cited 2017 Jan 20]. Available from: http:// www.who.int/immunization/research/development/dengue_ vaccines/en/

12. Tripp RA, Ross TM. Development of a Zika vaccine. Expert Rev Vaccines. 2016;15:1083-5. 